\title{
Two Forms of Realism
}

Making Sense of Rorty's Controversy with Brandom and Ramberg over Objectivity

\section{Yvonne Huetter-Almerigi}

\section{(2) OpenEdition \\ 1 Journals}

\section{Electronic version}

URL: http://journals.openedition.org/ejpap/1868

DOI: $10.4000 /$ ejpap. 1868

ISSN: 2036-4091

\section{Publisher}

Associazione Pragma

\section{Electronic reference}

Yvonne Huetter-Almerigi, «Two Forms of Realism », European Journal of Pragmatism and American Philosophy [Online], XII-1 | 2020, Online since 16 June 2020, connection on 26 June 2020. URL : http:// journals.openedition.org/ejpap/1868; DOI : https://doi.org/10.4000/ejpap.1868

This text was automatically generated on 26 June 2020 .

\section{(c) (i) (9)}

Author retains copyright and grants the European Journal of Pragmatism and American Philosophy right of first publication with the work simultaneously licensed under a Creative Commons AttributionNonCommercial-NoDerivatives 4.0 International License. 


\title{
Two Forms of Realism
}

\author{
Making Sense of Rorty's Controversy with Brandom and Ramberg over \\ Objectivity
}

Yvonne Huetter-Almerigi

\section{AUTHOR'S NOTE}

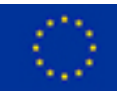

This article is part of a project that has received funding from the European Union's Horizon 2020 research and innovation programme under the Marie Skłodowska Curie grant agreement $\mathrm{N}^{\circ} 832636$.

1 Brandom's volume Rorty and His Critics (2000) is famous due to, as Jeffrey Stout puts it, "the most startling passage in Rorty and His Critics and one as surprising as any in the entirety of Rorty's published writings" (Stout 2007: 16). In this passage, Rorty agrees with Ramberg that the use of "getting things right," which Ramberg promotes based on Davidson, is fully compatible with his own approach, and declares the intention to use it in the future (Rorty 2000c). In the same volume, incomprehensibly for many, Rorty remains adamant about his refusal of Brandom's request to use his notion of "made true by facts" (Rorty 2000a). Philosophers sympathetic to the New Pragmatists' approach read the passages as an admission of Rorty's eventual failure to avoid truth and realism. Like Stout, they "do not see how to square" (Stout 2002: 52) Rorty's agreement with Ramberg while he continues to resist Brandom. As Stout puts it, "Ramberg and Brandom appear to be explicating the same pre-philosophical ideal of 'getting things right' in the somewhat different philosophical idioms of Davidson and Sellars, neither of which strikes me as inherently tainted by metaphysics" (2002: 52). ${ }^{1}$ Others, like William Curtis, hold that "Stout and others read far too much in Rorty's 'Response to Ramberg' [...] [T] here is ample evidence in Rorty's earlier writings [...] that suggests that he always held this 'reformed' position urged by Ramberg” (2015: 73).

2 In what follows, I will, for the first time, contrast both positions because I think there is a substantive difference between Rorty pre- and post-"Response to Ramberg" and there 
is a substantive difference between Ramberg's and Brandom's request. When Curtis claims that Rorty "always held" the "position urged by Ramberg" (2015: 73), he is addressing the critics of Rorty who falsely regard him to be a linguistic idealist and social constructivist. Indeed, Rorty never negated causal constraint, nor did he deny that the world is mostly independent from our thoughts. ${ }^{2}$ Yet, the point of Ramberg's piece (2000) is not to convince Rorty of "the brute resistance of the world," as Westbrook put it (2010:14), but to convince him of the inescapability of the normative and, hence, of the distinctiveness of the intentional vocabulary. After his conversation with Ramberg, Rorty holds that there are non-causal word-world relations where he formerly held that there are only causal relations. As Curtis rightly points out, he never held that there are no relations.

3 Before the debate, Rorty held versions of his Quine- and Davidson-inspired meaning holism, which translated his Sellars-inspired epistemological behaviorism into semantics. In epistemology, Rorty took from Sellars that "assertions are justified by society rather than by the character of the inner representations they express" and that "epistemic authority" is explained "by reference to what society lets us say" (Rorty 1979: 174). In semantics, Rorty, interpreting Davidson, thought that "The point of constructing a 'theory of truth of English' is not to [...] explain the relationship between words and the world, but simply to lay out perspicuously the relation between parts of social practice (the use of certain sentences) and other parts (use of other sentences)" (Rorty 1979: 261-2). Though the world causally constrains what we can say, it has no normative role in our linguistic practices. In his answer to Ramberg, Rorty, reinterpreting Davidson, conceded normative lines - "certain word-world relations which are neither causal nor representational" - running between world and speakers (Rorty 2000c: 374). This revision is as substantive as it can be, a revision that Rorty this has to be said very clearly - did not follow up on after the debate. But this does not diminish the importance of the concession and the difference it makes for how we can appropriate and build on Rorty today.

Now, I turn to the difference between Brandom and Ramberg and to why, in my opinion, Rorty agreed to use Ramberg's notion of "getting things right" but not Brandom's notion of "made true by facts."

\section{Apparent Congruities}

Besides being a contribution to the discussion of Davidson, Ramberg showed Rorty that his antiauthoritarian stance can be advocated more powerfully when constructed in the way Ramberg proposes. Ramberg makes two points: Firstly, he shows Rorty that there is a non-dangerous way of making use of a difference that Rorty formerly rejected - namely, the difference between the intentional and physical vocabulary, or the specialness of the "vocabulary of agency," as Ramberg calls it. Secondly, there is a non-dangerous way of using the notion "getting things right" and Rorty would do well to use it. The reason why Rorty accepts both parts is that the key to the first part - the difference between intentional and physical vocabularies - lies not in the irreducibility of the intentional to the physical and not in some sort of gap between body and mind, but in the inescapability of norms. Rorty writes: "agency [...] only appears if a normative vocabulary is already being used" (2000c: 372), which is a variation on Ramberg's: "descriptions emerge as descriptions of any sort at all only against a taken 
for granted background of purposive - and hence normatively describable - behavior on the part of the communicators involved" (Ramberg 2000: 362).

6 The second part, the introducing of what seems a form of realism, is congruent with Rorty's program, he says, because it links the theory of truth intrinsically to the theory of action: "Getting things right" means making them better suited to our purposes. Therefore, Rorty, from there on, should use or at least should not have objections against the notion "getting things right": "There are certain word-world relations which are neither causal nor representational - for instance the relation 'true of' which holds between 'snow is white' and snow, and the relation 'refers to' which holds between 'snow' and snow" (Rorty 2000c: 374).

7 Rorty arrives at these proclamations because, following Ramberg's considerations, he revises his understanding of Davidson's concept of triangulation: "It was a mistake to locate the norms at one corner of the triangle - where my peers are - rather than seeing them as [...] hovering over the whole process of triangulation. [...] It is not that my peers have more to do with my obligation to say that snow is white than the snow does, or than I do" (Rorty 2000c: 376). Similarly, Rorty writes in his response to Davidson in the same volume that:

The point of this doctrine [triangulation] is that you cannot get along with just holistic inferential relations between beliefs and statements (as coherence theorists tried to do) nor with atomic relations of being-caused-by (as realists fixated on perception still try to do). You have to play back and forth between causation and inference in a way which does not permit any of the corners of a triangle to be independent of any of the others. (Rorty 2000b: 78)

8 Is this not exactly what Brandom tried to do with his notion "made true by facts"? Brandom explicitly tried to show how "facts" enter the inferential game. The world cannot justify a claim, since justification is an inferential affair, but the world can make claims correct in the sense of true: "The representational model, after all, does not purport to tell us about justification (at least, not directly); its claim is that the use of our empirical vocabularies stands in normative semantic relations to the world, in that how things are determines the correctness of our claims in the sense of their truth" (Brandom 2000: 161). He continues, "I think one can understand facts as true claims, acknowledge that claiming is not intelligible apart from vocabularies, and still insist that there were true claims, and hence facts, before there were vocabularies" (Brandom 2000: 162). Brandom, in a second step, shows also how "facts" in his account enter the justificatory process:

In fact, the same strategy applied above to domesticate epistemic correctness as truth can be extended to domesticate epistemic correctness as justification or warrant. We can see the facts as standing in normative relations of justification to our claiming as well as in causal relations of triggering them. Indeed, we can see them as standing in the normative relations precisely because and insofar as they stand in the causal relations. (Brandom 2000: 165)

9 Given the last citation of Rorty above - on how you have to "play back and forth between causation and inference" - Brandom's account seems indeed very similar, if not interchangeable with how Rorty depicts Davidson's triangulation after reading Ramberg. Against this background, it is perfectly reasonable to ask why Rorty agrees with Ramberg but not with Brandom.

10 I do think the playing "back and forth" indicates a kind of problem since in order to "play back and forth" you need two realms between which to perform the maneuver. 
My claim is that in the way Ramberg proposes Davidson's "triangulation," there are not two strictly distinct realms and, therefore, also no gaps to bridge by "playing back and forth." This, I will show, is the reason why Rorty embraces Ramberg's version but not Brandom's, which implies two distinct realms.

\section{Differences}

11 Brandom's two realms appear as he differentiates between the act of claiming and what is claimed, or, more importantly, of what is claimable: "I want to say that facts are true claims in the sense of what is claimed (indeed, of what is claimable), rather than in the sense of true claimings" (Brandom 2000: 162). "With this distinction on board," he continues, "there is nothing wrong with saying that facts make claims true - for they make claimings true. This sense of 'makes' should not be puzzling: it is inferential" (Brandom 2000: 162). This means, as Brandom explains in Making It Explicit, they have no explanatory but only expressive use. True claims are "providing an expressive equivalent" of a "fact" (Brandom 1994: 328). For Brandom, "It is true that snow is white' is a semantic expression of a nonsemantic fact" (1994: 329). He makes overt use of the representational scheme which operates with two distinct realms, yet the representational power aspirations are domesticated because they are plausible only with reference to a vocabulary using these notions. One might say that authority remains solely at the angle of one's peers, to use Rorty's Davidsonian picture.

Yet, Brandom strengthens the non-vocabulary part by granting that: "There were no true claimings before there were vocabularies, because there were no claimings at all. But it does not follow that there were no true claimables" (2000: 162). He explains why: "For facts are true claims in the sense of what is claimed, not in the sense of claimings. If we had never existed, there would not have been any true claimings, but there would have been facts (truths) going unexpressed, and in our situation, in which there are claimings, we can say a fair bit about what they would have been" (Brandom 2000: 163).

Brandom's strategy is that whereas only social practices install authority, we do confer it in our representational language practice to the angle with the world insofar as the representational model, as cited above, purports "that the use of our empirical vocabularies stands in normative semantic relations to the world, in that how things are determines the correctness of our claims in the sense of their truth" (Brandom 2000: 161). Since we ourselves transferred authority, for Brandom no harm is done. But Rorty is not convinced:

Why am I so intent on resisting Brandom's attempt to reconcile the fact that facts are intelligible only relative to vocabularies with un-Davidsonian notions like "making-true" and "correspondence"? Because I think that nobody would have had a use for this cluster of notions unless they had a conception of beliefs cutting reality at joints which are not relative to vocabularies - which are Nature's Own, owing nothing to the human needs and interests which led us to dream up photontalk and baseball-talk. Without this cutting-at-the-joints imagery, nobody would ever have suggested that true beliefs were accurate representations of reality. (Rorty 2000a: 185)

Brandom thinks his approach is immune to this critique because "there is in this picture no contact between naked, unconceptualized reality and someone's application of concepts" (Brandom 2000: 165). I think Brandom is right that in his picture there is no direct contact, but there is naked, unconceptualized reality! 

Brandom, "concepts are always perspectival in so far as their contents are different for different individuals (different individuals have different inferential articulations for the same concepts)" (Kusch 2002: 255). But then Brandom goes on to suggest that "objects are "non-perspectival in a strong sense"' (Brandom 1994: 594, qtd. in Kusch 2002: 255). This is where objectivity comes in; what is shared by all perspectives is that there is a difference between what is objectively correct in the way of concept application and what is merely taken to be so, and objectivity lies in the perspectival form of our practice of attributing and endorsing beliefs and commitments. But Kusch says: "Contrary to what Brandom alleges, he has not shown that objects are "nonperspectival in a strong sense.' What he has shown is that the attributer of a de re belief-attitude does not treat the object as perspectival" (Kusch 2002: 258). "But this only shows," Kusch points out, "that de re attributers neglect the perspectival character of their beliefs about the object; it does not show that the beliefs and the objects are not perspectival. Of course they are perspectival" (2002: 258).

Kusch insists on perspectivity because this strengthens his own version of relativism. The point for me here is not to decide whether objects are non-perspectival in a strong sense $^{3}$ but to underline that Brandom takes them to be, as can be seen from his appeal to the already cited ancestral scenarios where there are truths "going unexpressed" (Brandom 2000: 163), and that the correctness of claims is determined by "how things are" (Brandom 2000: 161).

There are two points in particular in this account that are troubling from the point of view that I am attributing to Rorty-in-accordance-with-Ramberg. The first is exactly the part that Brandom thinks is his salvation and to which Rorty, apart from his answer to Ramberg, also could have subscribed: namely, the no-direct-contact-but-only-causalpressure part. I return to this below. The second point, one that troubled Rorty also before Ramberg's paper, is that there is a place for naked reality in Brandom's picture. "Unconceptualized reality" in Brandom's sense is not just a move in our current representational language game. It bears deeper, metaphysical implications; It is not just a notion in that it has ontological aspirations.

This can be seen from Brandom's concept of the "claimable." Brandom's system would be complete and work beautifully without the "claimable." The "claimable" adds nothing if not the flavor of the strong, unconceptualized, unchangeable part of reality reality without us. This is something that Brandom's system could not offer otherwise because Brandom starts from actual "claimings" and, as the system is inferential, authority lies only with the interlocutors and not at the angle of the world. This is so even if, as mentioned above, when we use the representational vocabulary, we transfer authority to the angle of the world. At this point, the transfer is simply a move inside the representational language game. Brandom, at this juncture, is right: "making true" works inferentially (Brandom 2000: 162). The problems arrive with the "claimable." If the "claimable" were only a derivative, reified, abstract version of actual claimings, then there would be no problem; the "claimable" would be a (rather useless) accessory, but surely not a concept that licenses talk about truths "going unexpressed" (Brandom 2000: 163) in ancestral time and facts beyond vocabularies. However, this is exactly the license Brandom wants. The function of the "claimable" is precisely to delimit the space for potential claims, and this space is enclosed by non-linguistic being (the ontos on). 

seen in his appeal to common sense and realist intuitions in the following example:

That old semanticist and modal logician Abraham Lincoln was asked "If we agreed to call the tail a 'leg,' how many legs would horses have?" His answer was: "Four, because you can't change how many legs horses have by changing the way we use words." This is surely the right response. One cannot change the nonlinguistic facts, in the unloaded sense, by changing linguistic ones. In the counterfactual situation envisaged, the words "Horses have five legs," would be true, but only because it would not say that horses have five legs, and so would not conflict with the fact that horses would still have four legs. (Brandom 2000: 163) They are unloaded in the sense that the material outer-world does not offer norms for how to talk about it; this is why Rorty, beyond his response to Ramberg, thinks that Brandom's "heart is certainly in the right place" (Rorty 1998: 135). Yet, Brandom's nonlinguistic facts are not unloaded when it comes to the stability and independence of unconceptualized reality, to objects being "non-perspectival in a strong sense."

Objectivity in Brandom is in the structure, in the perspectival form itself, not in content. That said, the "is-seems"-difference, which is built into our representational discursive practice, hangs on the idea that there is a way the world is, in a stable way, though we will never get a non-perspectival look at it. This "the way the world is beyond our descriptions" seems, at first sight, to be merely structuring the form of our discursive practice and not open to the charge of essentialism. Yet it is bound up with ontological commitments since what ultimately makes claims true is their reliability to the facts - where facts are not notions in a language game - though we do not have measures for checking the actual fit.

22 A further point is that not only the representational frame presumes that there is a way the world is, but Brandom himself does too. As Brandom writes: "We ought to have little sympathy with an author who, upon being accused of commitment to some objectionable thesis-idealism, let us say, or realism, or pragmatism, depending on one's sympathies - responds with outrage 'But I explicitly say on page 193 that I am not an idealist (realist, etc.)!' For that hardly settles that he is not also committed to it by other things in the book" (Brandom 1997: 197). In Making It Explicit as in Brandom's contemporary papers, there are points (see above) where he is committed to two realms that need to be bridged, between which to "play back and forth." This includes not only the causal vs. the normative realm but also language vs. the world. As a result, his approach is open to the accusation that it is a very elaborate and sophisticated version of the old scheme-content distinction ${ }^{4}$ because, in the end, though causation and inference have to be played back and forth a number of times, what makes "facts" facts is that they supersede vocabularies even if they are understandable only with reference to vocabularies. Therefore, in Brandom's approach, vocabularies are still played off against the world beyond vocabularies.

For Brandom it is important that there are facts prior to and beyond language. Ramberg's Davidson has no use for facts or the world without us. Ramberg offers Rorty the possibility to skip tedious questions of ontology once and for all because his version of objectivity, though having an "is-seems" distinction, operates neither with the semantic register of "how the world is" nor with ontological commitments to how the world is (in itself beyond us) because vocabularies and world are not played off against one another. 

independently of us existing facts enter, figure in, or determine the inferential game, like Brandom does. But he is making a point about how communication is possible how communication is a way of acting - and how rationality is brought into being via communication. In Ramberg's version there is no difference between claimables and actual claimings like there is in Brandom. No difference exists between what can be potentially claimed and what is actually being claimed because there are not two distinct realms that have to be put in connection. In Davidson "the contrast between truth and error - true belief and false belief [...] can emerge only in the context of interpretation, which alone forces us to the idea of an objective, public truth" (Davidson 1984: 170). distinction is part of our discursive practice. Yet, for Brandom what finally allows for the distinction are facts beyond vocabularies, whereas what allows for the distinction in Ramberg are successful interactions. In Davidson, and Ramberg,

[T]he objectivity which thought and language demand depends on the mutual and simultaneous responses of two or more creatures to common distal stimuli and to one another's responses. This three-way relation among two speakers and a common world I call "triangulation." (Davidson 2001a: xv)

The key here lies in the words "mutual and simultaneous." This is subtly but importantly different from how Rorty describes triangulation in his response cited above, as "playing back and forth between causation and inference." "Playing back and forth" is what Brandom does. In Ramberg's Davidson, you never get one angle in isolation in the way that Brandom appears to allow. Brandom first cuts the angles with me and my peers to get naked reality in his ancestral scenarios of unexpressed truths. Then the angle with reality gradually enters the inferential realm via the complex causal-inferential interactions described above. In Ramberg's Davidson, you always have all three corners together. This is the difference between the Davidson of "radical interpretation" where, "coherence yields correspondence" (Davidson 2001b: 307) - a "correspondence without confrontation" (Davidson 2001b: 137) - which is nearer to Brandom's picture, and the Davidson of "triangulation" (see Ramberg 2001). On the way Ramberg proposes Davidson's "triangulation" to Rorty, there are no time-slices available in which one single individual finds herself contemplating the world in front of (and divided from) her because the individual's thoughts and language are always already bound up with the world and her peers. The three corners of Davidson's triangle are, always and in every moment, "mutual and simultaneous"; they are an undividable package because with one angle missing there is no rationality. For Rorty, this is also the reason why Davidson uses "rationality, normativity, intentionality, and agency as if they were roughly co-extensive predicates" (Rorty 2000c: 371).

To put it still another way, for Davidson there aren't even angles, but only an undividable package of relations - relations which you cannot un-do and which bond the intentions and purposes of agents always and in every moment together with their common environment. Also for Ramberg's Davidson, just like for Brandom, there was a world before human beings came to exist. But, in sharp difference to Brandom for whom there are truths "going unexpressed," it had no meaning and no truth because "meaning" and "truth" require all three angles. Now, with us in the picture, just like in Brandom, we can make claims about ancestral time, but there is no way to curtail us 
and our present purposes, which triggers the question about that time in the first place.

Truth in Ramberg's sense of "getting things right" is a success-maker. It marks the successful interaction of all three angles, ${ }^{6}$ where language is neither understood as medium of explanation nor a medium of expression. Language is action; it directs and manipulates our (inter)relations. This is what convinced Rorty: the theory of truth is intrinsically connected with the theory of action. According to Rorty, Ramberg lets us see that "an account of truth is automatically an account of agency, and conversely. He helps us see that Davidson, like Dewey, is trying to break down the distinction between the knowing, theorizing, spectatorial mind and the responsible participant in social practices" (Rorty 2000c: 371), which are practices in and interacting with the world.

This is where, according to Ramberg, Rorty's concept of "redescription" comes in. It is not some sort of idealism or social constructivism, but "bringing salience to different causal patterns in the world, patterns with which we engage. And that is just the great ability that our language brings, this ability to reprogram our causal dispositions through salience-alteration" (Ramberg 2000: 363). We can highlight certain features or let them fade into the background. This process of highlighting and rearranging attention alters what reality consists in: "By changing our causal dispositions, redistributing significance across kinds, we affect how we engage with the world, and thus also the world. Indeed, if changing descriptive strategies [...] didn't have a causal impact on how things are, it would be hard to see how language could have evolved as a useful tool" (Ramberg 2000: 363). Ramberg's appropriateness conditions do not refer to the object only. The description does not have to fit the object - the description, to "get things right," has to fit the triangle. This is the important part and the difference with respect to Brandom. The "right" in "getting things right" marks successful interactions, not correct words in the sense of words opposed to a world beyond words, as is ultimately the case in Brandom's account of "facts," though, obviously, in Brandom, we have no methods to check the fit.

What does that mean for the horse and its legs? In Brandom, the horse will "always" have four legs because it has four legs. The non-perspectival form of the horse, the horse without us, is a "fact," where "facts" are established by language-games. Yet, what ultimately accounts for objectivity is the difference between our perspectives and the non-perspectivalness of the world beyond us. Our claims are correct if they get reality right (reality without us), although we are in Brandom's "sanitized version," as he calls it, never directly in touch with it.

31 Brandom's version is, in my opinion, both too weak and too strong for Rorty at the time of his concession to Ramberg. Brandom's version is too weak because there is no direct touch, and authority lies only at the angles with me and the peers. However, we can decide to put authority on the other angle; this is what Brandom recommends we do or what we are already doing in our representational language practice. Until this point it is - Brandom is right - "sanitized," as long as we agree that we are doing languagegames. Yet, and this is where Brandom's approach is too strong, I agree with Kusch that there is "naked reality" in Brandom - the object is "non-perspectival in a strong sense," although - this is the weak part again - there is "no bird's-eye view above the fray of competing claims from which those that deserve to prevail can be identified, nor from which even necessary and sufficient conditions for such deserts can be formulated" (Brandom 1994: 601). These claims seem difficult to hold together. 

We cannot not be in touch. But there is no "how things really are." This does not mean that we can make just any claim. We have to "get things right" and this entails that I, my fellows, and the horse are a package in the process of description and redescription. Authority is distributed. This is in Rorty's already cited passage: "It was a mistake to locate the norms at one corner of the triangle - where my peers are - rather than seeing them as [...] hovering over the whole process of triangulation [...] It is not that my peers have more to do with my obligation to say that snow is white than the snow does, or than I do" (Rorty 2000c: 376). This entails what Rorty himself calls a "partial reconciliation of pragmatism and realism" (2000c: 374). Also in Ramberg, there is no "birds-eye view" from which to decide between competing claims, but you can provide success rates. These success rates are not based on the accuracy of the objectdescription fit - objectivity is not guaranteed by the difference between our practice of concept application and "how things are." Claims are not "made true by facts," but they are based on the triangle. Claims do not have to "get things right" beyond vocabularies since if we "get things right" we cope successfully with our peers and the world. In this scenario, "copying" is not ensuring successful coping. The weakness of "copying" lies exactly in trying to get us out of the picture - in cutting an angle which instead is needed.

In both Brandom and Ramberg, there is no possibility to decide once and for all between competing claims. In Brandom, this is due to the fact that we cannot rise above our practice; hence we will never get a non-perspectival glimpse of the (only theoretically potentially available) non-perspectival object. In Ramberg this is due to the fact that our practices can change, and that with them, truth also will change, since, as noted, "getting things right" means taking account of the triangle and this means thinking together our (changing) needs and purposes and our common world. Further, the urge to decide between competing claims in addition to their rendering our actions successful is a hangover from representationalism, which in Ramberg's version really can be left behind. In Ramberg there just is no split between ontology and semantics or epistemology; or put differently, Ramberg's approach is "postontological" insofar as it skips questions regarding reality without us.

To apply this again to Brandom's example with the horse's legs, for Rorty at the time of his response to Ramberg, calling the "tail" a "leg" will not get the horse a fifth leg! We have to "get things right" in order to have success with our actions, and today calling the "tail" a "leg" does not render our interactions with the horse and our peers more successful. We cannot freely decide what "gets things right." But we can change the way in which we engage with the world through salience alteration. Therefore, there actually are possible ways in which horses do not have four legs; this is when their legs are no longer a salient feature because our practices have changed in a way that let the horse's legs fade into the background. In such a context, saying "the horse has four legs" will let us fall out of success because the horse will not have four legs. This is not just a change in linguistics, like, in Brandom's example, the "counterfactual situation envisaged, [where] the words 'Horses have five legs,' would be true, but only because it would not say that horses have five legs, and so would not conflict with the fact that horses would still have four legs" (Brandom 2000: 163). It is a change in our interaction with matter, which we are and with which we also engage linguistically. 

employing or describing but held captive by the representational picture. Once referential semantics are gone, ontology in the essentialist sense drops out as a corollary. This is what Ramberg showed Rorty. To be clear, the vocabulary-ontology divide does not structure Ramberg's approach. Ontology just is not at stake or in sight. The things we "get right" do not supersede vocabularies because words are not opposed to objects when it comes to what allows for the distinction between truth and error. For Ramberg, Davidson's “is-seems" distinction is post-ontological because the notion "leg" is (just) a way to cope - it helps and directs our interactions, where we, our peers and the world are one undividable package. The question what "leg" really means or refers to or what there is beyond our vocabularies has fallen off the agenda.

\section{Two Forms of Realist Intuitions} while he embraces Ramberg. For Stout, as I cited at the beginning, "Ramberg and Brandom appear to be explicating the same pre-philosophical ideal of 'getting things right' in the somewhat different philosophical idioms of Davidson and Sellars, neither of which strikes me as inherently tainted by metaphysics" (Stout 2002: 52). I hope to have shown that the "pre-philosophical ideal of 'getting things right" Ramberg and Brandom each aspire to is quite different.

For Brandom and Stout this pre-philosophical ideal points to representational realism in an "unloaded form", as Brandom would say - yet he would have had to show how the non-perspectivalness of the world beyond vocabularies does not occupy a crucial role in the overall structure of his concept of objectivity. The world without us still figures as the ultimate touchstone, though as a touchstone we will never touch and a touchstone that we do not directly compare our words with - this we do in our inferential practices. Yet, these practices are functioning according to the overall form that there is a difference between what we say and how the world really is. Brandom's is-seems-distinction hinges on there being a world beyond us; material reality is as it is. To the potential question, "are objects non-perspectival in a strong sense or does the total form of our inferential practices assume them to be?" Brandom's answer most probably would be "yes to both."

Brandom's version accommodates representational realist intuitions better, and his program is exactly this: to take the ecumenical instead of the revolutionary stance. For Brandom, no harm is done as long as we are aware that representationalism is an inferential affair. After Making It Explicit was published, Rorty wrote some recommendations to Brandom on how to face the likely upcoming accusations of relativism by advising him to be "more arrogant [...] and to situate his philosophy of language within an immodest metaphilosophical framework according to which philosophical reflection can reject [...] intuitions" (Rorty 1997: 177). One reason is that, according to Rorty, inferentialism, even in Brandom's causally constrained form, will never be enough to convince people with strong realist intuitions, so he might as well go with revolution. Another reason is that "rhetoric matters," as Rorty puts it his essay on Brandom in Truth and Progress (Rorty 1998, 132). This is the Rambergian point: descriptions alter our dispositions, and by doing so they interact with the world - this

European Journal of Pragmatism and American Philosophy, XII-1 | 2020 
is what the "language as tool" metaphor means. Brandom's version does not actively alter our dispositions, nor does it want to.

The pre-philosophical intuition Ramberg starts from is that we are able to interact successfully with our environment. This is a form of realism that does not sharply divide words and the world. Ramberg's answer to the old pragmatist question, "Do we need copying to cope?" is a clear "no."

Ramberg provides more powerful tools for two of Rorty's interconnected aims: his antiauthoritarianism and his openness to change. In Ramberg's version, Rorty is right; there is still "no authority called Reality before whom we need bow down" (Rorty 2000c: 376) because Ramberg "does not offer criticisms of or warrant for descriptive strategies by appealing to the way the world is" (Ramberg 2000: 368). We can still toss out our "old intuitions" and are not slaves to essences or orders of being while simultaneously capturing what in representational language would be the pressure and resistance of the outer-world, yet without representationalism and its alleged dualisms. Put another way, in Ramberg's version, there is no playing "back and forth."

Pushing this line of thought further would also go in directions that, at first sight, do not seem compatible with Rorty's interests. Rorty's Humanism is touched; in Ramberg's picture, we do not rely only on ourselves but on the world as well, though in ways that do not confer the world authority over us, nor us over the world. The question is whether Humanism today is still serving the goal that Rorty wanted it to serve: is Humanism still the most suitable tool for our purposes? Does it still guarantee Rorty's antiauthoritarianism and change? In Ramberg's version, the concept of "authority" is freed from foundational imagery and offers therewith new ways of conceptualizing "authority" in which "authority" is not necessarily connected to "hierarchy" and "domination." Ramberg's version could even offer ways to toss out the concept of "authority" altogether, and this would alter our dispositions a fair bit. Yet, these last thoughts are very tentative and need much more elaboration.

My intention here was only to insist on the difference between Brandom's and Ramberg's requests. The difference between their respective approaches seems minimal but, as I hope to have shown, this small difference has a large impact on how we understand our conceptual agency and our ways to engage with the world. Brandom's ultimately dualist version confines agency to the inferential realm which stands across from a world that is as it is in itself. Rorty, in his answer to the debate, does not criticize Brandom for making the causal-normative distinction - a distinction which Rorty, until his answer to Ramberg, advocated himself. This rightly inspired scholars in the past to think Rorty's approach could still be hampered by dichotomies (e.g. Gascoigne 2008, Levine 2020, Tartaglia 2016) - dichotomies that apply to Brandom as well. The difference between Rorty and Brandom in this regard is that in Rorty the distinction - which, on my reading, he abandons in his answer to Ramberg - functioned to argue for eliminativism, whereas in Brandom, ultimately, the distinction functions to petrify the world.

43 Ramberg's version offers a whole new set of possibilities to understand reality and our linguistic interactions because it does not play the world off against vocabularies. In this account, the world, though equally material and independent from our thoughts, is not a bloc that stands in front of us but is the environment in which we are enmeshed and from which we cannot be divided. Depending on which features of this world we highlight - which become "salient" and which fade in the background - reality 
changes. This has a material impact on our lives and is where the ethical and political potency of this approach lies, which is precisely the reason why Rorty agreed to it.?

\section{BIBLIOGRAPHY}

BRANDOM Robert B., (1994), Making it Explicit: Reasoning, Representing, and Discursive Commitment, Cambridge, Cambridge University Press.

BRANDOM Robert B., (1997), “Replies,” Philosophy and Phenomenological Research, 57 (1), (March), 189-204.

BRANDOM Robert B., (2000), "Vocabularies of Pragmatism: Synthesizing Naturalism and Historicism," in Id. (ed.), Rorty and His Critics, Oxford, Blackwell Publishers, 156-82.

CURTIS William M., (2015), Defending Rorty: Pragmatism and Liberal Virtue, Cambridge, Cambridge University Press.

DAVIDSON Donald, (1984), “Thought and Talk," in Id., Inquiries into Truth and Interpretation, Oxford, Clarendon Press, 155-70.

DAVIDSON Donald, (2001a), "Introduction," in Id., Subjective, Intersubjective, Objective, Oxford, Clarendon Press, xiii-xviii.

DAVIDSON Donald, (2001b), “A Coherence Theory of Truth and Knowledge," in Id., Subjective, Intersubjective, Objective, Oxford, Clarendon Press, 137-53.

GASCOIGNE Neil, (2008), Richard Rorty: Liberalism, Irony, and the Ends of Philosophy, Cambridge, Polity Press.

KUSCH Martin, (2002), Knowledge by Agreement, The Programme of Communitarian Epistemology, Oxford, Oxford University Press.

LEVINE Steven, (2008), "Rorty, Davidson, and the New Pragmatists," Philosophical Topics, 36 (1), Spring, 167-92.

LEVINE Steven, (2010), "Rehabilitating Objectivity: Rorty, Brandom, and the New Pragmatism," Canadian Journal of Philosophy, 40 (4), December, 567-90.

LEVINE Steven, (2020), draft version, "Rorty, Davidson, and Representation," to be published in: Alan Malachowski (ed.), Wiley-Blackwell Companion to Rorty, Downloadable from Levine's academia.edu page [um-boston.academia.edu/StevenLevine].

RAMBERG Bjørn, (2000), "Post-Ontological Philosophy of Mind: Rorty versus Davidson," in Robert B. Brandom (ed.), Rorty and His Critics, Oxford, Blackwell Publishers, 351-70.

RAMBERG Bjørn, (2001), "What Davidson said to the Sceptic - or: Antirepresentationalism, Triangulation, and the Naturalization of the Subjective," in T. Kotatko, P. Pagin \& G. Segal (eds.), Interpreting Davidson, Stanford, CSLI Publications, 213-36.

RAMBERG Bjørn, (2014), “Irony's Commitment: Rorty's Contingency, Irony, and Solidarity,” The European Legacy, 19 (2), 144-62. 
RORTY Richard, (1979), Philosophy and the Mirror of Nature, Princeton, Princeton University Press.

RORTY Richard, (1982), "Introduction: Pragmatism and Philosophy," in Id., Consequences of Pragmatism, Minneapolis, University of Minnesota Press, xiii-xlvii.

RORTY Richard, (1997), “What Do You Do When They Call You a 'Relativist'?," Philosophy and Phenomenological Research, 57 (1) (March), 173-77.

RORTY Richard, (1998), "Robert Brandom on Social Practices and Representations," in Id., Truth and Progress. Philosophical Papers, Vol. 3, Cambridge, Cambridge University Press, 122-37.

RORTY Richard, (2000a), "Response to Brandom," in Robert B. Brandom (ed.), Rorty and His Critics, Oxford, Blackwell Publishers, 183-90.

RORTY Richard, (2000b), "Response to Davidson," in Robert B. Brandom (ed.), Rorty and His Critics, Oxford, Blackwell Publishers, 74-80.

RORTY Richard, (2000c), "Response to Ramberg," in Robert B. Brandom (ed.), Rorty and His Critics, Oxford, Blackwell Publishers, 370-77.

SтоUт Jeffrey, (2002), "Radical Interpretation and Pragmatism: Davidson, Rorty, and Brandom on Truth," in Nancy Frankenberry (ed.), Radical Interpretation in Religion, Cambridge, Cambridge University Press, 25-52.

sтоUт Jeffrey, (2007), “On Our Interest in Getting Things Right: Pragmatism without Narcissism," in Cheryl Misak (ed.), New Pragmatists, Oxford, Clarendon Press, 7-31.

TARTAGLIA James, (2016), “Rorty's Ambivalent Relationship with Kant," Contemporary Pragmatism, 13 (3), 298-318.

WESTBROOK Robert, (2010), "A Tale of Two Dicks," Paper delivered at the conference "Confines of Democracy: The Social Philosophy of Richard Bernstein," 18 May 2010, Universidad de Castilla-La Mancha, Toledo, Spain. Download: [urresearch.rochester.edu/ institutionalPublicationPublicView.action?institutionalitemId=12801] (last accessed: 5.6.2017).

\section{NOTES}

1. See also e.g. Gascoigne (2008: 213-21). For an account that points to the possibility of Rorty having a point in resisting Brandom, see Levine (2008, 2010, 2020). Levine's approach differs from mine insofar as he moves his support of Rorty's argumentation in order to strengthen New Pragmatism. Levine is pointing with Rorty to weak spots in New Pragmatism that, according to Levine, should be corrected (2008: 189). My interest in this article is to spell out in detail the difference between Brandom's and Ramberg's respective approaches in the debate. These details, I believe, point to a possibility of ameliorating the concept of "realism." However, that is beyond the scope of this article.

2. See e.g. Rorty (1982: xxvi).

3. As I will argue below, having this question and wanting to answer to it, is part of the problem. The question itself needs to be eliminated.

4. "Old" because what is played off against each other are language vs. empirical content.

5. "Mutual and simultaneous" is congruent with Rorty's description if one strongly emphasizes the second part: "You have to play back and forth between causation and inference in a way which does not permit any of the corners of a triangle to be independent of any of the others" (Rorty 2000b, 78; emphasis added), though, I would insist, that "playing back and forth" is a metaphor that creates confusion because it does presuppose two realms. 
6. "Interaction," here, does not mean "playing back and forth." More aptly one should say "action" instead of "inter-action," where "action" always includes the mutual and simultaneous dependence of all three angles in every moment and without the possibility to make cuts.

7. The first person who heard, read, and insisted I pursue this project was Richard Bernstein. So, it is due to him that the project took its start. But it is due to Bjørn Ramberg, with his immense knowledge, wisdom, and mentoring skills, that I advanced it to completion; this article is unthinkable without his support. Earlier drafts of the paper received sophisticated and perspicuous comments from Chris Voparil, Neil Gascoigne, and Michael Bacon. My thanks also go to two anonymous reviewers for their valuable remarks. I presented earlier versions of the paper during a masterclass with Bernstein in Munich; at the 3rd European Pragmatism Conference in Helsinki; and at the workshop "Truth versus the Rhetoric of Truth: Authority, Realism, and Power" in Oslo. I am most grateful to the audiences and commentators of these events.

\section{ABSTRACTS}

There is a famous puzzle in Rorty scholarship: Did or did Rorty not subscribe to a form of realism and truth when he made concessions regarding objectivity to Bjørn Ramberg in 2000? Relatedly, why did Rorty agree with Ramberg but nevertheless insist upon disagreeing with Brandom, though large parts of the research community hold their two respective requests for shifts in Rorty's stance to be congruous? The present article takes up the discussion and tries, for the first time, to make sense of Rorty's insistence that there is a difference between Brandom's notion of "made true by facts" and Ramberg's notion of "getting things right" by showing that Ramberg's appropriateness-conditions are fully compatible with Rorty's revised interpretation of Davidson's concept of "triangulation," whereas Brandom's inferential "made-true-by-facts"-language game is not. The reason why Rorty agrees with Ramberg but not with Brandom, I argue, is that Brandom's contemporary concept of objectivity, as developed in his contribution to the debate and in his Making It Explicit, works with a scheme-content distinction, whereas Ramberg's Davidson-based version does not. As many of his critics suppose, Rorty's concession to Ramberg entails a substantive revision of Rorty's position, not just a clarification. However, this new position is not in conflict with Rorty's most important commitment, namely his antiauthoritarianism. The revised account still does not bind him to the forms of realism and truth that his critics favor. The article explains to which forms of realism and truth Rorty's concessions to Ramberg commit him instead.

\section{AUTHOR}

\section{YVONNE HUETTER-ALMERIGI}

Università di Bologna

yvonne.huetter[at]gmx.net 